\title{
School Grade Repetition in Brazil: History of the Configuration of a Political and Educational Problem
}

By Natália Gil

Abstract- This article intends to argue that the movement of students through the Brazilian mandatory school only acquires signs of an educational political problem from the 1930's on. It indicates that the current sense of the notion of student failure came to be defined only in the twentieth century, although it was possible to fail students since before. It intends to show further that, in articulation with political and cultural changes in education - such as the emergence of compulsory school, the definition of grade-based model of school, and the primacy of homogeneity of classes - the emergence of better and systematic statistics after 1931 contributed decisively in defining the conditions for the possibility of inclusion of student failure as a problem on the political agenda.

Keywords: history of education, educational statistics, school performance, educational policy, student achievement.

GJHSS-C Classification: FOR Code: 370199

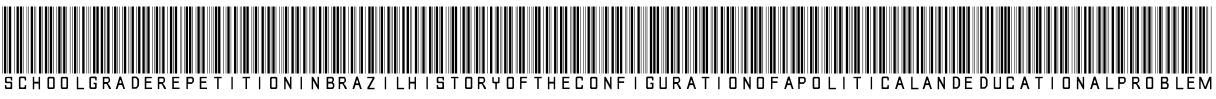

Strictly as per the compliance and regulations of:

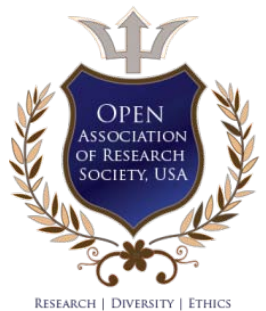

(C) 2021. Natália Gil. This research/review article is distributed under the terms of the Attribution-NonCommercial-NoDerivatives 4.0 International (CC BY-NC-ND 4.0). You must give appropriate credit to authors and reference this article if parts of the article are reproduced in any manner. Applicable licensing terms are at https://creativecommons.org/licenses/by-nc-nd/4.0/. 


\title{
School Grade Repetition in Brazil: History of the Configuration of a Political and Educational Problem ${ }^{1}$
}

\author{
Natália Gil²
}

\begin{abstract}
This article intends to argue that the movement of students through the Brazilian mandatory school only acquires signs of an educational political problem from the 1930's on. It indicates that the current sense of the notion of student failure came to be defined only in the twentieth century, although it was possible to fail students since before. It intends to show further that, in articulation with political and cultural changes in education - such as the emergence of compulsory school, the definition of grade-based model of school, and the primacy of homogeneity of classes - the emergence of better and systematic statistics after 1931 contributed decisively in defining the conditions for the possibility of inclusion of student failure as a problem on the political agenda.
\end{abstract}

Keywords: history of education, educational statistics, school performance, educational policy, student achievement.

\section{InTRODUCTION}

r $\mathrm{n}$ the second half of the twentieth century, grade repetition emerged in educational debates and on the public agenda as a serious problem of the Brazilian school, one of great proportions and which needs to be denounced, understood and resolved. Otaíza Romanelli (1978), when examining school statistics between 1930 and 1971, indicated that the expansion of the school in this period showed "insufficient supply", "low internal performance" and remarkable "social discrimination". This stemmed from the realization that enrollment growth was significant in those decades, but did not offer vacancies to all schoolage children; of the students enrolled in the first grade of primary education, few graduated to the following grades, dropping out of the school along the way; and school failure and dropout rates were higher among students from the popular strata.

Interested in understanding the processes of social discrimination within the school and committed to criticism of the role assumed by school psychology in legitimizing this discriminatory process, Maria Helena de Souza Patto defended in 1987 the thesis that resulted in

Author: Professor and researcher at University of Rio Grande do Sul (Brazil).e-mail: natalia.gil@ufrgs.br

\footnotetext{
1 This article is the result of a cross-institutional project (UFRGS, UNICAMP, USP "A escola obrigatória e seus alunos: acesso, permanência e desempenhos" (1870-1970)", funded by CNPq/Brazil (Case No. 454937/2014-8). A version of this article was published in Portuguese in the Revista Brasileira de Educação (2018).

${ }^{2}$ As will be discussed later in this paper, school failure is the result of poor student performance in school evaluations reported at the end of a cycle, which may be annual or not, and repetition refers to the grade or step repetition phenomenon at which the student failed.
}

the book The production of school failure, which is in keeping with these analyses. In her research, the author claimed that poor school performance of poor children was generated by selective mechanisms internal to the institutional dynamics and was not due to students' cognitive deficiencies, or to any deficit or cultural difference. Patto (1993, p.346) also pointed out that the research allowed us to understand that "the failure of elementary school is managed by a scientific discourse that, hiding in its competence, naturalizes this failure in the eyes of all those involved in the process".

The presence of more detailed statistics on school failure and dropout and the educational debate that presented the issue as a serious distortion of the Brazilian school led to some political actions aimed at presenting solutions. Thus, different initiatives were proposed, such as the basic cycle, acceleration classes and school reinforcement classes. Márcia Jacomini (2010, p.22) mentions that

Although the discussion about annual non-failure policies has taken place in Brazil since the 1920s, it was not until the 1960s that some municipal and state public education networks organized the teaching in a non-serial way and adopted annual non-failure policies.

The author adds that, "in general, proposals for the organization of teaching in cycles have arisen from the need to find alternatives to face the high rates of school failure and dropout and to construct a less selective and excluding school" (Jacomini, 2010, p. .22).

It must be admitted, however, that student failure has occurred since long before. From the installation of modern school in Brazil, still in the colonial period, students are expected to undergo exams, in which they can pass or fail. The notion of repetition itself, however, could only arise when the grade school is established at the end of the nineteenth century. It is from the existence of the physical separation of students according to the grades indicated in the curricula, alongside the adoption of simultaneous teaching, that it became necessary that, at the end of a school year, those who did not present learning corresponding to the minimum expected, in terms of mastery of the program of the grade attended, would resume it from the beginning the following year. That is, to repeat the same grade.

Therefore, events such as the existence of students who did not learn the contents provided in the program at the expected pace, the fact that they 
continued in school for longer until their mastery of curriculum contents became evident, the fact that they would not attend school as soon as they or their families felt they had already learned enough, or that they would not even advance further in learning, all of these were not necessarily considered as a political-educational problem. Only later will these occurrences be taken as distorting the path of students. It is therefore interesting to locate and understand the period in which these events are taken as a problem in educational talk, specialized discourses (by pediatricians and psychologists, for example) and political talk.

In this article I intend, first, to make some theoretical-methodological remarks regarding the understanding of statistics and the words they mobilize. I also indicate the conceptualization used on what is established as a problem on the political agenda. Second, I present a brief discussion about the emergence of exams as a disciplinary practice in modern school, the exceptional nature that examination rituals assume in the path of students who attended school in the nineteenth century in Brazil, and the slow definition of the annual rhythm as characteristic of compulsory school. Next, I try to understand how, in the first republican decades, the adoption of serial school represented a slow and decisive process of change in school culture, in which the circulation of specialized discourses on the efficiency of teaching and normality standards in children's school performance had a strongly prescriptive effect from practices and behaviors. Discussions regarding the importance of testing and the advantages of homogeneous class organization have engendered the widespread circulation of the belief that most individuals learn in the same way and at the same paces. Finally, I argue that the emergence of systematic, higher quality statistics on education - especially on enrollment, attendance and failure - after 1931 is a determining factor for the perception of educators and public managers of that period of what is now considered as "distortions" of students' learning paths, giving rise to a debate that emphasized students deficiencies as the cause of the phenomenon and which proposed actions in the scope of educational policy to make teaching more efficient, but not necessarily more adapted to the students' needs.

\section{Words, Numbers and Problems: Some TheOretical-Methodological CONSiderations}

It is largely due to the emergence of more comprehensive and systematic educational statistics in the 1930s and 1940s that certain student movements through school grades can be perceived, analyzed and described as "distortions". In this sense, the debates about failure have as a condition of possibility the production of statistics that allow to see the characteristics of students' movement in the school, to evaluate the pace of learning and to establish, from this, normality standards. The production of numbers depends, however, on the prior establishment of categories that guide the collection of data, that is, it depends on the definition of certain social situations expressed in words. Annie Fouquet (1995, p.135-136) emphasizes that the statistician's job is to count what was previously socially defined and that "the numbers he publishes are the result of countless descriptions of reality often made without him, and of which he is only the counter". These definitions and descriptions are the result of a historical process in which words take on specific meanings according to agreed upon and often not clearly expressed social uses.

Thus, the work presented here dialogues with the assumptions of the History of Concepts, as proposed by Reinhart Koselleck. According to this author,

without shared concepts there can be no society and, above all, there can be no unity of political action. On the other hand, concepts are based on socio-political systems that are far more complex than one is made to suppose from their understanding as linguistic communities organized under certain key concepts (Koselleck, 2006, p. 98).

It also highlights, from this, that Social History therefore cannot dispense with the contributions of the History of Concepts, insofar as it endeavors to understand "from when the concepts can be rigorously used as indicators of political and social transformations of historical depth" (Koselleck, 2006, p.101). It is thus important to examine the semantic field of concepts in order to identify the use of terms in the social and political sphere by contemporaries and previous generations, as well as perceive the conflicts by the definition of terms, which aim to maintain or impose political and social positions.

Beyond these observations, the socially ascribed importance of statistics has largely been based on the shared belief that they would present a neutral and objective description of reality, ensured by the universality of numbers and the unequivocal character of carefully chosen words in the composition of categories. However, statistics are far from having the neutrality that is often ascribed to them. Produced from defined purposes, by particular individuals and restricted to the possibility of presenting only numbers, constrained by certain categories, statistics show partial aspects of society. The choices made - in deciding what subjects can and/or should be counted, in defining the categories that are the basis for the collection of primary data, in selecting what should be included in the tables of disclosure of results, in comparisons made, etc. - are neither automatic nor evident and determine the image obtained from the procedures that 
characterize the production of this type of knowledge. As Jean-Louis Besson (1995, p. 32) warns, "we must now realize that we are not dealing with a simple picture that we could compare with what we see." That is, statistics do not "reveal" reality. Rather, they integrate and participate in its construction insofar as they conform to the ways in which the real is perceived. ${ }^{3}$ Such choices, although not fully conscious, are linked to the motivations that led to doing the research and correspond to necessary cutouts that result in an always necessarily partial angle.

The choice of this theoretical approach defines my intention to show that the school situation that in the twentieth century comes to be described as a problem of student flow through the school is a historical construction that involves both numbers and words. In this sense, it is important, on the one hand, to consider, as suggested above, that statistics are representations constructed from certain conditions and that they end up collaborating in the construction of certain social situations, although they are referred to as an instrument of mere description of these situations. On the other hand, it is important to stress that, in the historical analysis of these processes, it must be considered that statistics are produced linked to words (categories) whose choice and definition precede the collection of numbers. Such words have no unambiguous meaning in their own period of use and, over time, are interpreted in different ways.

In view of these considerations, it is important to mention the senses found, from the investigation of the documentary corpus, for the following terms: failure, retention and repetition. Failure refers, in the period examined, to the results in exams or final evaluations indicating that the student did not attain the minimum performance level expected. Retention is a consequence of this failure, since it determines, assuming the serial teaching model, the student's inability to follow in the normal flow from one grade to the next. On the other hand, repetition points to the phenomenon of students remaining in the school because they were retained in a certain grade, who will be submitted to attending it again. The understanding of these senses, as already argued, is not given for any historical period. Thus, we need to consider that the current sense that we give to these terms has been formed progressively. It should be remembered that for a long period - and this is also the case today in certain levels or modalities of teaching - in the face of retention, students often dropped out of school. Such dropping out was often seen as quite natural, allowing us to

\footnotetext{
${ }^{3}$ In this regard it should be noted that it is assumed here that statistics exert what Bourdieu (1998) calls the "theory effect", since, by producing forms of world's intelligibility, they create the conditions of existence of what they describe.
}

suppose that the school results were experienced as a sentence of the individuals' (in) abilities and (im) possibilities to continue going to school. It is only with compulsory schooling, linked to the social realization of the advantages of schooling for the whole population, that the permanence in school will prevail, even in the face of negative outcomes, such as failure. It is in this context that a student taking the same grade again becomes permissible and, increasingly, obligatory, making repetition quantitatively expressive.

That is, these movements were not always assumed as a political-educational problem. These occurrences will be considered as distortions of the path of students only in the twentieth century, when the expectation is that everyone attends and completes primary education. Until the 1930s, in Brazil, the debate revolved around the issue of children's access to school, evoking both the lack of schools and adequate facilities to serve the population and families' lack of interest in sending and keeping their children in school. From that point on, there was concern that even if children went to school, still they had no guarantee of pass and permanence in the institution. As a result, debates about the need for policies that could make teaching more efficient and prevent students from failing and dropping out of school were recurrent. In the 1940s, the issue of grade repetition is mentioned in reports, but it is only in the 1970s and 1980s that there is a significant debate describing it as an undesirable phenomenon to be addressed by public policy makers.

It is thus important to emphasize that social situations only engage governmental officials when certain conditions are present. John W. Kingdon (1995, p.109-110) ${ }^{4}$, in a study that seeks to understand how items enter or leave the political agenda and why some items and alternatives gain prominence, while others are neglected, states that "situations are defined as problems when we come to believe that we should do something to change them. Problems are not simply the conditions or external events themselves; there is also a perceptual, interpretive element." For a given situation to be assumed as a problem, a set of elements must be present, such as the value given to the observations, the comparisons made and the categories mobilized to describe this situation. Thus, the same situation can be understood as a problem or not, depending on the value that the subjects responsible for the definition of the agenda give to it and if they consider that it is an issue on which it is possible to act. Also, comparisons between situations can cause a problem to be delineated. Kingdon (1995, p. 11) points out that "if one is not achieving what others are achieving, and if one believes in equality, then the relative disadvantage

\footnotetext{
${ }^{4}$ I would like to thank Libia Aquino for alerting me about the relevance of John Kingdon's studies to understand the configuration of political problems.
} 
constitutes a problem." He mentions further that "people will see a problem quite differently if it is put into one category rather than another. Thus, much of the struggle over problem definition centers on the categories that will be used and the ways they will be used" (Kingdon, 1995, p.111).

Kingdon emphasizes that problems are not entirely self-evident and therefore one must understand what processes and elements cause a particular situation, which would otherwise be disregarded, to receive attention from decision makers. At this point, statistics play an important role, as do the debates that take place from them. Governmental and nongovernmental agencies regularly monitor various activities, and this is followed by historical numbers and series of numbers that are assumed as indicators of various situations. It is worth noting, as the author warns, that "such indicators or studies are not used primarily to determine whether or not a problem exists; such determination is a matter of interpretation" (Kingdon, 1995, p. 91). In the context of this article, I intend to argue that failure has existed since the emergence of the modern school, but it will only be viewed as a political-educational problem in the twentieth century. It is at the confluence of the debates that take it as an issue worthy of attention and of the existence and analysis of educational statistics that one can identify some of the conditions of possibility for school failure to be configured as a political problem.

\section{ili. School Exams and the Definition OF A Time TO LEARN}

Exams have existed since the emergence of modern school. For example, in 1599, when Ratio Studiorum was published, providing detailed guidance for teaching in Jesuit schools, regular written examinations were planned to be held, in which students could show the results of their learning (Saviani, 2007). Also in the work of Jan Amos Comenius, Didactica Magna, published in 1657 and which provides the foundations of the Protestant pedagogy of the seventeenth century, exams, exercises and weekly tests are proposed (Saviani, 2007). Foucault (1987, p. 166) highlights the disciplinary character of this school practice and states that in Modernity "the school became a sort of apparatus of uninterrupted examination that duplicated along its entire length the operation of teaching." He points out, as an example, that the Brothers of the Christian Schools wanted their pupils to be examined constantly. Such considerations make it necessary to recognize that the examination, as a systematic written or oral practice of proving learning, has been foreseen since at least the sixteenth century.

In the nineteenth century, in Brazil, the imperial legislation does not go into detail on the development of teaching and evaluation activities. Thus, examinations will take place in the first letter schools following provincial regulations. For Rio Grande do Sul, for example, according to the Regulations of 1876 and 1927, examinations and exercises should be performed annually in rituals coordinated by the general inspector (Hawat, 2015). Date and time would be defined in advance, and an examining committee would be constituted. Joseane El Hawat (2015, p.64) points out that

the students considered fit to take the examinations were individually questioned by the examiners in all subjects according to the level of education reached - 1st or 2nd. After this stage of oral evaluation, which respected the time that each examiner considered "sufficient to form his judgment," the student took a written test by writing an excerpt, to evaluate spelling and calligraphy, and solving arithmetic problems.

From the performances observed in these assessments, students were graded into simply approved, fully approved, approved with distinction, or failed.

In reference to schools for girls in Minas Gerais, Monica Yumi Jinzenji describes public examinations in the 1830s. According to the author,

the publication of examinations results in newspapers usually occurred a few days after it and did not vary much in form, always bringing the same idea that a citizen witnessed the examination and then reported the event. He described the number of students present, the contents examined, and the students' performances, highlighting those fully approved or advanced and, in the end, the teacher's speech at the opening of the exam (Jinzenji, 2010, p.183).

She also highlights the low attendance of students on these occasions for possibly varied reasons, including the embarrassment of public exposure to a situation when they were not always able to show high achievement.

However, it would be a mistake to consider that the experience of participating in exams was generalized to the childhood at that time. It should be remembered that very few individuals came to attend school in the nineteenth century. Even among those who did go to school and long enough to be able to undergo this type of evaluation, there is evidence that the usual practice was to send for examination only students whose previous assessment by teachers indicated that they could pass. Joseane El Hawat, analyzing the minutes of the examinations carried out in the public schools of Porto Alegre between 1873 and 1919 , notes that few students submitted to the ritual in comparison to the total enrolled. Clearly, in that context, not all the individuals who attended class were submitted to examinations.

Few individuals carried out the public tests provided by the laws and the precariousness that characterizes the production of school statistics in the period results in the absence of a systematic survey 
and publication of numbers of failures. A social understanding of school exclusion prevailed as a matter of course, and indeed, in quantitative terms, that was the rule. An analysis of enrollment books in Porto Alegre shows that the time spent in school until at least the 1920 s is very short ${ }^{5}$. Most of the students attended school for only 1 or 2 years; those who attended the same school for 3 and 4 years were rare, and those who remained for more than 5 years were even rarer.

It should also be noted that the period of the year in which children could be enrolled in school, that is, when they could begin to go to school, is extremely broad. For Rio Grande do Sul, decree no. 89, of 1897, in art. 46, indicated that children's registration could be done from the beginning of the year until September. In several of the books analyzed, initial registrations appear concentrated in the first months of the year, from January to April. At any rate, the most noteworthy is the continued enrollment of students throughout the entire year, almost always up to the deadline set by law (October or November). This implies considering, as Rita de Cássia Gallego proposes, that school times were defining themselves slowly. From documents of São Paulo, this author emphasizes the historicity of these aspects by remembering that

school time, as one of the social times, is also diverse and plural. It consists of a social system of temporal references from which the functioning, rhythms, coordination and synchronization of interactions within the school are defined, organized and regulated; thus, it is the result of a cultural and pedagogical construction (Gallego, 2003, p.18).

With regard to examinations and failure, it should be emphasized that the very notion of the calendar year as a time limit for checking learning and for setting the outcomes, such as pass and failure, is something that will only be effectively established in the twentieth century.

Also the ages of learning were being established in this process. Maria Cristina Gouveia points out that, in Brazil, compulsory schooling laws established the age group of students, corresponding roughly to what Rousseau indicated as the learning period, that is, between 7 and 12 years. According to the author, in the Brazilian case,

the nineteenth century incorporated pedagogical discourses that defended the educability of childhood, the civilizing role of education and, within this reflection, the definition of an ideal period for the acquisition of elementary education. In the 1800s, this was increasingly understood as having to take place in school spaces. Public education projects were

\footnotetext{
${ }^{5}$ We analyzed 22 registration books of isolated schools of Porto Alegre, located in Rio Grande do Sul Historical Archives, covering the period from 1895 to 1919. In those documents the characteristics of the entrance in school were examined input of the institution, as the age of the students for instance, and the trajectories of the students enrolled.
}

directed to the child in the 7-14 years age bracket (Gouveia, 2004, p. 275).

In agreement with this author's and other interpretations, the results of the empirical research we did on enrollment books has evidenced that the process of defining childhood by the student condition was slow. For example, in 1897, the laws of Rio Grande do Sul indicated that "only children from 7 to 13 years of age can be enrolled in public schools" (Decree 89, article 39). An analysis of the enrollment books, however, shows the possible presence of 4-6-year-olds and also the attendance of some individuals above that age bracket. This allows to argue that the normalization of learning times and the definition of the annual progression in school, although predicted earlier, did not prevail in school practices until at least the 1920s. Well, to assume failure and repetition as distortions of the students' flow through the school grades presupposes the standardization of these times in the laws and in the discourse that prescribes pedagogical practices. But it also implies a change in school culture, and this is not an immediate and automatic consequence of that standardization. Thus, it is with the broad adherence of pedagogical thinking and teaching practice to the idea ofhomogeneity and standardization, as well as with the effective expansion of vacancies in compulsory school, that makes it possible to see in the exclusion of students who do not learn an educational problem.

\section{Grades and Homogeneity of Classes}

The organization of primary education in grades along the nineteenth and twentieth centuries throughout the West will be constituted as denotative of the pedagogical rationality considered as coherent, durable and adequate for the universalization of education (Souza, 2006). "Based on the homogeneous classification of students, the existence of several classrooms and several teachers" (Souza, 1998, p.15), the use of grades in schools will imply, among other things, the development of an appropriate architecture, the creation of specific furniture and learning materials and a new understanding of school times and learning rhythms.

In Brazil, the first initiative in this sense took place in São Paulo, in the midst of the proposals headed by the republican elite that wanted to organize society in line with the new regime. In 1893, school groups were created in São Paulo, where the teaching was organized in grades, each arranged in its classroom governed by the same teacher. This implies emphasizing that the grade-based school in São Paulo presupposed simultaneous teaching, in which the contents were taught to all students in the same way and at the same time. 
The adoption of simultaneous teaching and grades was based on the understanding of the possibility and necessity of organizing homogeneous classes. It was considered that, in order for the school to be efficient, able to teach in the timeframes established by the official programs, it was necessary to improve the criteria of class composition so that students with equivalent learning performance and content proficiency levels were put in the same grade. The make-up of these classes was based primarily on two resources. The first one focused attention on the prior assessment of each child's abilities, even before the beginning of schooling, resorting to psychological, schooling, and developmental tests. The second was the school-based assessment proper, which relied mainly on mastery of the contents taught, leading to passing or failure at the end of the school year. Thus, the student who did not prove sufficient mastery of the contents taught in a particular grade was prevented from proceeding to the next grade, having to restart the grade in which he/she failed. That is, he repeated the year. In this arrangement, failure, retention and repetition are understood as necessary for the proper and efficient functioning of the school.

If it worked as planned, this model would allow each grade level to correspond to the age range of students. So, ideally, children would start going to school at age 7 in first grade, would be 8 in second grade, and so on. Nevertheless, the regularity in that flow was not confirmed in the daily life of schools, and already in the first decades of the twentieth century there were frequent discussions about the distortions that prevented the functioning of the model. But what was called into question was not the appropriateness of the assumption that supported the model, but students' disabilities and limitations. Extensive debates and numerous studies sought to identify "abnormal" children in order to avoid that they could hinder the smooth running of the school. Based on this understanding, improvement of teaching presupposed the development of tests that allow to identify and classify slow or incapable students.

Tests for selection and classification of students were then taught and widely recommended to teachers as a way to help improve the quality of primary education. In psychology textbooks for teachers, which circulated in the early twentieth century, it was commonly

recommended the use of intelligence tests, especially those developed by Binet, which allowed to identify retarded children and determine each student's mental level, in order to direct them to the most appropriate type of education for their individual needs (Lima and Viviani, 2015, p.103).

Alfred Binet was one of the most important researchers of experimental psychology in Europe and, since the late nineteenth century, he engaged in developing procedures supposedly capable of measuring mental functions (Monarcha, 2009). In 1904, Binet was appointed by the Ministry of Education in France to join a commission whose assignment was to diagnose students' mental level "for subsequent creation of special classes and application of educational programs appropriate to the levels of intelligence found" (Monarcha, 2009, p.186). The French government was particularly interested in identifying students with low intellectual capacity in order to remove them from regular schools, intending thereby to ensure a more efficient pedagogical achievement. In this sense, Claparède, an enthusiast of the proposal, said:

We are at a time when the issue of abnormal children has begun to worry the spirits in France. While in Germany, Belgium, and Switzerland a special education for this category of children had long been in place, nothing had yet been provided to them in the French school organization (apud Monarcha, 2009, p.186).

Studies by Binet have been read with interest by the Brazilian elite that intended to organize the nation through schooling. With a strongly liberal bias, these individuals were engaged in "evolving biometric practices and propose an education that is consistent with innate abilities, which was considered to be the way to settle the dilemma of legal equality and biological difference" (Monarcha, 2009, p.208).

Of the psychological tests proposed for the Brazilian school in this period, the "ABC Test" deserves mention 6 . Developed by Lourenço Filho, at the time occupying the chair of Pedagogy and Psychology of the Escola Normal da Praça da República, in São Paulo, and strongly based on Binet's studies, the "ABC tests", a set of tests meant to evaluate motor coordination, memory, attention, etc., sought to identify students' maturity levels for learning to read and write. In the book Introdução ao estudo da Escola Nova, 1930, Lourenço Filho (apud Monarcha, 2009, p.221) stated:

On a trial and error basis, experimental psychology succeeded in obtaining practical means for investigations necessary to classify individuals, which is possible today without long or hard work through relatively simple objective means. These means are the psychological tests, small exams under well-defined conditions, and whose significant values are only set after biostatistical investigations.

Through them, one not only gets to the rational organization of homogeneous classes, to selective and differentiated (or "tailored", as Claparède called it) instruction, but also to the scientific classification of abnormal intelligence, the organization of classrooms or schools for supernormal individuals, professional guidance and selection, discrimination of temperaments and special skills.

The principles of pedagogical rationale were clearly expressed there, whereby it would be possible to identify the retarded children, for whom standard

\footnotetext{
6 It is noteworthy that only in the 1930s the "ABC test" will be discussed in educational media and used in schools.
} 
education would be unproductive, and to organize selective classes in the first elementary grade, each being educated according to their pace. Thus, it was thought to be possible to arrange homogeneous classes in which simultaneous teaching would be not only possible, but efficient.

Faced with similar concerns, the School Enforcement and Statistics Division, Federal District, attempted the homogeneous classification of students between 1933 and 1935. André Paulilo (2012, p.42) emphasizes that "the formation of classes in those years was a technical possibility not only to organize the school, but to make it achieve, optimize its processes and ensure learning." The composition of these classes resorted to the tests in vogue at the time. This process, according to the author,

not only added standardized tests to the field of school observations, but considered students' behavioral events in order to distinguish a class of students from another. The degree of attention devoted to the objective settings of the classroom situated more than the children, their achievement, their fitness, their expressive manifestations, and character in the scope of public education policies (Paulilo, 2012, p.42).

The classificatory rationality framed the conviction that the more accurate the procedures for homogeneous distribution of students, the better the results in terms of learning. In 1936, the Department of Education and Public Health published a bulletin titled Failures in elementary school, which presented a study on the issue carried out at the request of Almeida Júnior, then Secretary ${ }^{7}$. Luiz Gonzaga Fleury, author of the study, claimed that one of the causes of failure was the "heterogeneous classes, whether in degree of student learning, or their mental index" (São Paulo, 1936, p.17). He stressed further that this cause could not be avoided in isolated schools - where repetition rates were, in fact, higher, he said - or even in the small school groups, but it seemed undeniable the need for better and more comprehensive student selection processes and organization of classrooms in other schools. In another bulletin published by the same department, Noemy Silveira Rudolfer, of the Applied Psychology Laboratory of the Institute of Education, reported that in a class whose grouping has taken place randomly (i.e., did not follow any selection criteria), there will likely be $16 \%$ strong, $16 \%$ weak and $68 \%$ intermediate students. It then concluded that, in this way, teaching would always be inadequate for a significant portion of students. This warranted the provision of a detailed sequence of procedures that should be used in schools, such as the assignment of

\footnotetext{
${ }^{7}$ We reviewed 18 bulletins published by the Educational Board of the Department of Education and Public Health of São Paulo, between 1936 and 1938, during the administration of Almeida Júnior.
}

students to strong, intermediate and weak groups, the double promotion scheme in the school year, the organization of special classes for the most severe cases, and use of tests (ABC and Dearborn and Ballard), as well as the consideration of the academic performance of the previous year.

It should be noted that the emphasis on the homogeneity of the classes meant, as highlights Rosa Fátima de Souza (2006), the establishment of a contradiction: a greater efficiency was sought so as to allow democratization of schooling, while at the same time it strengthened selectivity and school exclusion. According to the author,

on the pedagogical level, the establishment of divisions in schools enabled a better performance of the school institution, but the school became more selective because the grouping of students in homogeneous classes supposed favoritism of the best at the expense of the "weak" students. In addition, the classification in courses generated improvement of exams and created the notion of repetition, which would constitute one of the greatest problems of elementary education of all times (Souza, 2006, p.45, original italics).

It is clear, therefore, already in the early 1900s, that repetition appears as a notion and failure begins to appear in official documents as a matter deserving attention. However, neither had yet been featured as an issue to be managed by the Brazilian education policy makers. We must consider that the specialized discourses that supported teacher training activities and official speeches that sought to prescribe legally authorized school practices during the first republican decades, make us see the existence of these issues. But, in quantitative terms, school attendance still remained very restricted. On the one hand, it is important to point out that, until the 1930s, a very small portion of the population went to school, whatever it was, and remained there for a short time. On the other hand, even with the continuous increase in access to education throughout the twentieth century, it took more than has been assumed for most students to attend grade-based schools, governed by teachers who had been trained in accordance with modern pedagogical discourses (which taught to teach simultaneously in homogeneous classes, for example), arranged according to the requirements mentioned above. These two elements allow us to understand why, despite the earlier circulation of skilled and official discourses about school selectivity, failure and repetition do not appear as a political-educational problem before 1930. Add to this the lack of well-organized statistics to be able to account for school attendance in the country, showing the number of students who passed and failed and repeaters and dropouts. In other words, the number of enrollments was still small, and those enrolled were not always subjected to the times and paces imposed by the law and modern pedagogy, and the ability of the 
state to know these phenomena quantitatively was still insufficient.

\section{School Statistics and the Visibility of Failure}

The production of school statistics was improved throughout the 1930s, expanding the categories collected and advancing in terms of technique $^{8}$. In 1930, the Ministry of Education was created and soon a division specifically designed for the production of educational statistics was proposed to be part of it ${ }^{9}$. In 1937, the creation of INEP gave a fresh impetus in this direction, since one of the functions of the new body was to conduct studies on the educational situation of the country, including the organization of more reliable and complete statistics.

In 1931 the Inter-Administrative Agreement of

Educational and Related Statistics was signed, an unprecedented initiative in the country designed to articulate efforts between federal agencies in conducting these surveys. This agreement will effectively allow to conduct more systematic and regular surveys covering the entire national territory. Also, it will press federal units to seek these data, fill out forms, and follow standard categories. Although this process is full of flaws and gaps, often highlighted in reports by those in charge of data compilations, it provided some organic quality in statistical production and resulted in a significant amount of information on enrollments. These figures allowed to develop interpretations and analyses of school movement, expansion of enrollments, and flow irregularities over the next decade.

Beside the effective expansion of access to school observed after 1930, the possibility of having a greater amount of reputable, good quality statistical data allowed to see school failure, repetition and dropout as statistically significant phenomena. The very systematic publication of figures alone allowed to see the flow distortions, which perhaps had existed for a long time but without the visibility provided by the numbers. The increase in the absolute number of enrollments will also assume, by the mere size of the figures, a surprising quality.

In 1936, in the above-mentioned bulletin Failures in elementary school, an analysis of failures in elementary schools of São Paulo was carried out by means of the school statistics available for the period.

\footnotetext{
${ }^{8}$ This is a process that Brazilian statistics in general go through in the same period. We have, for example, the creation of IBGE in 1937, experts' agreement on the higher quality of the 1940 census data, increasing mathematization of demographic procedures in the following decades. For further details about the organization of statistics in Brazil, see Senra (2006; 2014).

${ }^{9}$ In 1931, with the creation of the Ministry of Education, the General Board of Information, Statistics and Dissemination was founded. In 1939, it was renamed as Statistical Service of Education and Health (SEES).
}

The study focused on the data of 17 municipalities in the region of the State capital. In this region, in 1935, of the 116,060 children taking exams, 48,824 failed, which meant a $42 \%$ failure rate. The analyses in the Bulletin show that Almeida Junior's consideration of the statistics is not naive. Indeed, the author states that "failures are accurate numerical data; but the criteria that determine them, as we know, change from school to school" (São Paulo, 1936, p.3). He argued that it was necessary to understand that "there are 'lowish' decision makers, who are content with little, but there are also "highish" ones, willing to tighten the belt of passes" (São Paulo, 1936, p.3). He thus expresses the ability to take numbers only partially, due to variations such as the one mentioned. With regard to failures, for example, he does agree that they indicate a problem in the state school system, but his argumentative emphasis is otherwise as he mentions, by the way, that "promotion is important because it means efficiency of informative education - but this does not exhaust school functions" (São Paulo, 1936, p.3).

Reports in the INEP, published between 1939 and 1944 by the federal government ${ }^{10}$, have also featured a discussion of the flow of students in elementary school. In these publications, the primary axis of the analysis is the enrollment of children in primary education. The most common is the comparison of enrollment totals at various times. From this, the enrollment growth rates in each state are calculated and then compared to the national average. In the Bulletins, the discussion on school performance often refers to the ability to enroll a significant contingent of the school population. The issue of passes rarely appears as worthy of attention. They are, however, present at times. In Bulletin No. 19, for example, there are data on growth of primary education institutions, graduated teachers, general enrollments, and information on pass and course completions: "It should be noted that the movement of passes in general, and course completions, especially in ordinary elementary school, showed, in the same period, a higher growth than that of enrollments" (Ministry of Education and Health, 1942, p.15). From this it follows: "Not only more

\footnotetext{
${ }^{10}$ With regard to the documents at the federal level, in the research that supports the argument presented here we analyzed especially those produced by the Education and Health Statistical Office (SEES), coordinated by Teixeira de Freitas, and the National Institute of Pedagogical Studies (INEP), organized by Lourenço Filho. Both bodies were subordinate to the Ministry of Education. In the former, we analyzed the series "Teaching in Brazil," published between 1939 and 1946. In the latter, INEP Bulletins between 1939 and 1944 were analyzed. In 1944, the INEP created the Brazilian Journal of Pedagogical Studies, whose articles have also been considered in this analysis. Another journal we consulted was the Brazilian Statistics Journal, published since 1940. In addition to these documents, some books of authors who took part in discussions about educational statistics in the period were consulted too.
} 
students were able, therefore, to attend schools, but also a higher percentage of students earned the benefit of passing and completing courses" (Ministry of Education and Health, 1942, p.15).

In a Bulletin entitled Teaching in Brazil in the five-year period 1932-1936, published in 1939, it is argued that, in order to be able to appreciate the "real work" and the "effectiveness of teaching", it would be necessary to examine the movement of enrollments, promotions and course completions. The observation makes one assume that the performance of teaching would be based on two interrelated elements: the first was student attendance to classes, without which, it was believed, the progress of the second factor - namely, the result of the year-end exams - was unlikely. Lourenço Filho, in charge of the publication of the Bulletins, emphasizes in this regard that "the number of school units indicates the supply of education. The general registration, its demand. But the true measure of the result of school work will only be provided by promotion and course completion rates" (Ministry of Education and Health, 1939, p.33, original italics). At the time, for general primary education, the provided data were as follows:

Table 1

\begin{tabular}{|c|c|c|c|}
\hline Years & Registration & Pass & Rate \\
\hline 1932 & 2071437 & 831223 & $40 \%$ \\
\hline 1936 & 2750014 & 1153212 & $42 \%$ \\
\hline
\end{tabular}

(Ministry of Education and Health, 1939, p.33)

Note that less than half of the registered students passed in the period.

The bulletin General situation of primary education, published in 1941, features an item entitled "General aspects of teaching performance", which provides general enrollment data, the percentage of passed students in relation to total enrollments, and course completions. With regard to these data, the following analysis is provided: "The general pass rates, calculated upon the effective enrollments or remaining students at the end of the year, portray [...] the real teaching achievement, allowing to acknowledge the overall deficiency of the school system" (Ministry of Education and Health, 1941, p.40, added italics). According to this document, in 1937 the pass rate was $52.1 \%$. Despite the mention, which indicates that these numbers are perceived as a problem in Brazilian primary school, the most prominent discussion in relation to achievement is around the so-called "exodus", "avoidance" or "defection" of students. In 1937, of 2,702,383 individuals enrolled in primary education, 417,479 would have left school early (15.45\%).

Noteworthy in this regard is a debate between Teixeira de Freitas and Lourenço Filho, held in the 1940s, which shows the importance ascribed to the issue by the very commitment of both in arguing, and indicates interpretations in dispute. In 1940, the Brazilian Statistical Journal brings an article entitled, "Demographic dispersion and education" by Teixeira de Freitas (1940a). This same study was deepened and developed in certain points to be presented in a public session of the Brazilian Society of Statistics, in November 1940, under the title "School dropout in the Brazilian primary education" (1940b). The same journal would publish in 1941 an article in which Lourenço Filho reports his disagreements about the analysis presented in that study. Finally, in response to Lourenço Filho's criticism, one last article by Teixeira de
Freitas was published, "Still on school dropout in the Brazilian primary education" (1941).

Several aspects are discussed by the authors in these articles. One of the significant differences between the authors concerned repetition rates. It should be emphasized that this problem had not featured the educational debate with the severity with which it came to be mentioned in the second half of the twentieth century. Rather, it was considered a natural and inevitable element in school movement - just like dropout, to a certain degree. Teixeira de Freitas points to the evidence of a marked improvement of achievement in second as compared to first grade, as well as in the third compared to second grade, although this last difference was weaker. The author points out that

This improvement, however - one must say - should not be interpreted as a rapid elevation of the mental level of the pupils, or as a greater efficiency of teaching in higher grades. It is obvious that it stems from the progressive selectivity with which the later series are constituted, by virtue of the actual dropout seen, which naturally eliminates the least apt or least devoted students from the student body (Teixeira de Freitas, 1940a, p.504, italics added).

It follows from this the inconsistency, pointed out by Lourenço Filho, in using, in that statistical study, an equal dropout rate to each of the different grades of primary education, as well as the option to disregard the occurrence of repetition of the same grade for more than once. He criticizes, for not being what was observed in fact, the "criterion used, which was to compute the repetition just once in the 1st year, two in the 2nd, and three in the 3rd" (Lourenço Filho, 1941, p.543). He goes on to argue that "higher rates of simple repetition, or its multiple incidence, are present precisely in the first grades or degrees of the course. And these, of course, contain the largest number of students" (Lourenço Filho, 1941, p.543), and completes stating 
that "as can be seen in official reports, repetition for three, four and even five times in the 1st grade occurs even in urban school systems, such as in the Federal District" (Lourenço Filho, 1941, p.543).

In his response to this criticism, Teixeira de Freitas (1941, p.572, original italics) says Lourenço Filho would have misread the table in the study:

But reread, our dear Professor Lourenço Filho, the table in question, noting the meaning of abbreviations. And then you will see it does not show what you supposed, but exactly "the abstraction of the particular case of multiple repetition of the same grade". Take, for example, the movement of the 3rd grade in 1936. The three portions there allude, right, to repeaters; but they are not repeaters of the grade (the 3rd) more than once, but new or repeaters of the 3rd grade for the first time, but who were previously repeaters - of one, other or both preceding grades (1st and 2nd), never, however, more than once in each - likewise the established assumption.

Once clarified that what seemed to refer to multiple repetitions of the same grade was not so, it is fitting to ask why the author ignored this phenomenon in his analysis. According to him, as there are no studies or data that match the whole country with regard to the occurrence of multiple repetitions, a technical device was used, namely, to make a substitution, with negligible error, considering all repeaters as simple. Teixeira de Freitas (1941, p.578) argues that "statistically, we are considering such students if not rigorously equivalent, at least as minimally disparate so that they can in practice be considered equal". For doing so, the author claims that for the purpose of the study, which was to know the time when each generation would have dropped out of school, this device would be satisfactory.

Teixeira de Freitas considered that multiple repetition was not so significant as to be necessary to consider it. It is worth to remember that the conclusions the author draws from his statistical study point primarily to the dropout problem. So, what he wants to emphasize is that children leave school before completing the minimum acceptable years of schooling he considered at that time. Therefore, it is reasonable that he gives little importance to multiple repetition since, following his reasoning, one must admit that instead of staying in school doing the same grades several times, most failed children, with more or less resistance, ended up dropping out of school altogether. Lourenço Filho, however, does not have the same view. According to him, a complete analysis of the dropout phenomenon "would take the rates of dual grade repetition, especially important in the 1st grade, where the variety of student rating criteria is so great from one to another educational system" (Ministry of Education and Health, 1941, p. 38).

It is also interesting to note that Lourenço Filho argues for the need to consider that failures in the 1st year not always have the pedagogical significance of an actual failure. That's because, he said, "in fact, we do not have in our schools a first grade to be held normally in a year of studies" (1941, p.544). That is, in some regions, in the same school, there was a "delayed" first year and an "advanced" one. Fernanda Cristina Campos da Rocha (2013) identifies this situation by analyzing the registration books of school group Sabará, in Minas Gerais, between 1907 and 1916. According to the author, the current practice in that institution was to divide the first-year program into two parts, each developed over one school year. Until 1912 the documents contain the names "1st year of the 1st half" (referring to the content provided for the first half of the 1st year) and "1st year of 2nd half." From 2013, such documents contain the words "1st year delayed" and "1st year advanced". Under these circumstances, "retention is much more related to school practices of the group, in an attempt to be able to cover the content under the program" (Rocha, 2013, p. 10). The author emphasizes that younger children - of the 1st year of the 1st semester or 1st year delayed - were not even submitted to exams, especially those between 6 and 7 years of age, because they are not considered yet ready for evaluation. In this sense, Lourenço Filho (1941, p.544) argued that one should consider that "often, for students, parents, and the effect of the appreciation of the work of the teachers themselves, students passing from a 1st year $\mathrm{A}$ to a 1 st year $\mathrm{B}$, or from delayed to advanced, meant promotion".

You may notice from this analysis that what gives rise to debate is, indeed, the existence of statistics on the flow of students through the school. These numbers were not produced in order to measure failure, repetition or even the dropout phenomenon. The intention was primarily to follow the expansion of enrollments and the scope of Brazilian primary education. However, the existence of this information will give visibility to initially unforeseen issues, such as repetition and dropout. In this sense, the documents analyzed are inaugural ${ }^{11}$ of an important debate, which hitherto had no conditions to be addressed. Even if failure, repetition and dropout have been configured as possible moves of students through the school before 1930 - as they are tied to the emergence of modern school and then the adoption of the grades model - it is statistics that that make their quantitative dimension visible and expressive, allowing them, in some measure, to be taken as problems on the political agenda, as suggested in Kingdon's analysis (1995).

\footnotetext{
11 Although they may not be the only ones, as the survey was restricted to only Rio Grande do Sul, São Paulo, Minas Gerais, Distrito Federal and the documentation published by the central government MEC, INEP, SEES and IBGE.
} 


\section{Final REMARKS}

This article was intended to argue that, although school exams and student failure existed since the installation of modern school in Brazil, even in the colonial period, is only from the 1930s that poor school results enter the political agenda as a problem of national education. To admit the existence of school exams does not mean that all the students were subjected to these rituals. In the nineteenth century, only those deemed fit by teachers and education inspectors, from little explicit criteria, took the exams. At such times, they could pass or fail - simply, fully or with distinction. As compulsory schooling consolidates and it is established that the annual grades should organize the paces and times to learn, during a slow process that is only defined in the Republic, a decisive process of change in school culture is witnessed. In this sense, the circulation of specialized discourses of teaching efficiency and the normal standards in children' school performance ends up in a heavily prescriptive feature of practices and institutional behaviors. Tests and the primacy of homogeneous classes are part of this process and significantly mark the relations between students, teachers and subjects. It is, however, linked to the production of more systematic, higher quality educational statistics that one realizes the existence of a political and educational debate on issues related to students flow through the school, especially on failure and dropout, in the 1930s and 1940s.

In the following decades - 1950, 1960, 1970 and 1980 - it is known that the issue continued to be discussed with characteristics that deserve to be better understood, which motivates the continuation of research on the subject. It is notable, though, the force with which this same issue has come back to the debate now, after more than two decades (following the constituent and the constitution of 1988), whose emphasis on educational discussion and the proposition of policies for education tended to the design of an inclusive school, open to diversity, instead of the selective and exclusive school that was established in Brazil during the nineteenth and twentieth centuries. We may not have been sufficiently aware of the fact that, in the context of schools and social debate, this discussion has not occurred with the same emphasis that it had in academic and intellectual circles of education.

\section{References Références Referencias}

1. ALMEIDA JÚNIOR, A. Repetência ou promoção automática? Revista Brasileira de Estudos Pedagógicos, Rio de Janeiro, n.65, p.3-15, jan.-mar. 1957.

2. BESSON, Jean-Louis. A ilusão das estatísticas. São Paulo: UNESP, 1995.
3. BOURDIEU, Pierre. Descrever e prescrever: as condições e os limites da eficácia política. A economia das trocas lingüísticas: o que falar quer dizer. $2^{\mathrm{a}}$ ed. São Paulo: EDUSP, 1998. p.117-126.

4. FOUCAULT, Michel. Vigiar e Punir. 10.ed. Petrópolis/RJ: Vozes, 1987.

5. FOUQUET, Annie. As estatísticas no debate social. In: BESSON, Jean-Louis. A ilusão das estatísticas. São Paulo: UNESP, 1995. p.135-148.

6. FREITAS, M. A. Teixeira de. Dispersão demográfica e escolaridade. Revista Brasileira de Estatística, Rio de Janeiro, n.3, p.497-527, jul.-set. 1940a.

7. A evasão escolar no ensino primário brasileiro. Revista Brasileira de Estatística, Rio de Janeiro, n.4, p.697-722, out.-dez. 1940b.

$8 . \quad$. Ainda a evasão escolar no ensino primário brasileiro. Revista Brasileira de Estatística, Rio de Janeiro, n.7, p.553-642, jul.-set. 1941.

9. GALLEGO, Rita de Cássia. Usos do tempo: a organização das atividades de alunos e professores nas escolas primárias paulistas (1890-1929). São Paulo: USP, 2003. Dissertação (mestrado em Educação). Programa de Pós-Graduação em Educação, Universidade de São Paulo.

10. GOUVEIA, Maria Cristina Soares de. Tempos de aprender: a produção histórica da idade escolar. Revista Brasileira de História da Educação, São Paulo, n. 8, 2004, p. 265-289.

11. HAWAT, Joseane Leonardi Craveiro El. Os saberes elementares matemáticos nas escolas isoladas de Porto Alegre: avaliações, programas de ensino e livros escolares (1873-1919). Porto Alegre: UFRGS, 2015. Dissertação (Mestrado em Educação). Programa de Pós-Graduação em Educação, Universidade Federal do Rio Grande do Sul.

12. JACOMINI, Márcia Aparecida. Educar sem reprovar. São Paulo: Cortez, 2010.

13. JINZENJI, Mônica Yumi. As escolas públicas de primeiras letras de meninas: das normas às práticas. Revista Brasileira de História da Educação, São Paulo, n.22, p.169-198, jan.-abr. 2010.

14. KINGDON, John W. Agendas, alternatives, and public policies. New York: Harper Collins College Publishers, 1995.

15. KOSELLECK, Reinhart. Futuro passado. Contribuição à semântica dos tempos históricos, Rio de Janeiro, Contraponto/Editora PUCRio, 2006.

16. LIMA, Ana Laura Godinho; VIVIANI, Luciana Maria. Conhecimentos especializados sobre os problemas de rendimento escolar: um estudo de manuais de psicologia e da Revista de Educação. História da Educação, Porto Alegre, v. 19, n. 46, p. 93-112, mai.-ago. 2015.

17. LOURENÇO FILHO. "A evasão escolar no ensino primário brasileiro". Revista Brasileira de Estatística, Rio de Janeiro, n.7, p.539-552, jul.-set. 1941. 
18. MINISTÉRIO DA EDUCAÇÃO E SAÚDE. O ensino no Brasil no qüinqüênio de 1932-1936. Rio de Janeiro: INEP, 1939. (Boletim n.1)

19. Situação Geral do ensino primário. Rio de Janeiro: INEP, 1941. (Boletim n.13)

$20 . \quad$ Organização do ensino primário e normal. Estado de São Paulo. Rio de Janeiro: INEP, 1942. (Boletim n.19)

21. MONARCHA, Carlos. Brasil arcaico, Escola Nova: ciência, técnica e utopia nos anos 1920-1930. São Paulo: Ed. UNESP, 2009.

22. PATTO, Maria Helena Souza. A produção do fracasso escolar. São Paulo: T.A.Queiroz, 1993.

23. PAULILO, André Luiz. A infância cercada: as políticas de controle da população escolar nas reformas educacionais do Distrito Federal entre 1922 e 1935. LOPES, Sônia de Castro; CHAVES, Miriam Waidenfeld (Orgs.). A história da educação em debate: estudos comparados, profissão docente, infância, família e igreja. Rio de Janeiro: Mauad X, 2012. p. 37-50.

24. RIBEIRO, Sérgio Costa. A pedagogia da repetência. Estudos Avançados, São Paulo, n.12, v.5, p.7-21, 1991.

25. RIO GRANDE DO SUL. Decreto n. 89, de 2 de fevereiro de 1897. Reorganisa a instrucção primaria do Estado. Leis, decretos e actos do governo do Estado do Rio Grande do Sul de 1906. Porto Alegre: Officinas Typogr. de Echenique Irmãos \& Cia, 1907.

26. ROCHA, Fernanda Cristina Campos da. Trajetória de alunos em um grupo escolar mineiro, entre 2907 e 1916: o tema da repetência escolar. Anais do VII Congresso Brasileiro de História da Educação, Cuiabá/MT: SBHE, 2013.

27. ROMANELLI, Otaíza Oliveira. História da educação no Brasil (1930-1973). Petrópolis, RJ: Vozes, 1978.

28. SAVIANI, Dermeval. História das idéias pedagógicas no Brasil. Campinas: Autores Associados, 2007.

29. SÃO PAULO. Secretaria da Educação e da Saúde Pública. Diretoria do Ensino. As reprovações na escola primária (O fenômeno das reprovações. Análise das causas. Medidas contra o mal. Dados estatísticos). Boletim n.7, 1936.

30. SENRA, Nelson de Castro (Org.). História das Estatísticas Brasileiras (1822-2002). Rio de Janeiro: IBGE, 2006. v.2: Estatísticas Legalizadas (c.1889 C.1936).

31. Organizando a coordenação nacional: estatística, educação e ação política na Era Vargas. Rio de Janeiro: IBGE, 2014.

32. SOUZA, Rosa Fátima de. Templos de civilização: a implantação da escola primária graduada no Estado de São Paulo (1890-1910). São Paulo: Editora da UNESP, 1998.

33. Espaço da educação e da civilização: origens dos grupos escolares no Brasil. In:
SAVIANI, D.; ALMEIDA, J. S.; SOUZA, R. F.; VALDEMARIN, V. T.. O legado educacional do século XIX. Campinas: Autores Associados, 2006. p. 33-83. 